\title{
Convergence between Marketing Approaches and the Aims of the Public Administrations: Towards an Optimization of the Citizen Relationship Management $(\mathrm{CiRM})$ in Morocco
}

\author{
El Yachioui Maryam, Aomari Amina
}

Mohammed V University in Rabat, Morocco

\begin{tabular}{|c|c|}
\hline & ABSTRACT \\
\hline $\begin{array}{l}2016 \text { Research Leap/Inovatus Services Ltd. } \\
\text { All rights reserved. } \\
\text { DOI: } 10.18775 / \mathrm{jibrm} .1849-8558.2015 .21 .3003 \\
\text { URL: dx.doi.org/10.18775/jibrm.1849- } \\
8558.2015 .21 .3003 \\
\end{array}$ & $\begin{array}{l}\text { Traditionally, there is a tendency to think that administration and marketing are two } \\
\text { antagonistic notions. Marketing is the science of designing the supply of a product according to } \\
\text { the analysis of consumer expectations and taking into account the capacities of the } \\
\text { organization as well as all the constraints of the socio-demographic, competitive environment, } \\
\text { legal, cultural in which it evolves. For Butler and Collins (1994) marketing has shifted from } \\
\text { transactional marketing, rather product-oriented to relational marketing, more client-oriented, } \\
\text { which corresponds more to the expectations of public administrations regarding their relations } \\
\text { with the citizen, especially the user. But in Morocco, there is a marketing myopia in the public } \\
\text { sector. Indeed, this industry often complains about the lack of citizens' interest in their services } \\
\text { and products. These citizens become more demanding and must be satisfied. This article thus } \\
\text { has a twofold objective: first, to show wherein the marketing myopia in Moroccan Public } \\
\text { Administrations lies, in order to define the heart of their business, and second, to propose a } \\
\text { marketing mix for these administrations to optimize their Citizen Relationship Management } \\
\text { (CiRM) and see how e-administration responds to a marketing approach. }\end{array}$ \\
\hline
\end{tabular}

\section{Introduction}

According to Levitt (1960) marketing myopia is defined as a disease of the managers and executives of many companies who fail to take a broad view of their business and therefore put growth at risk through lack of marketing orientation. In Morocco, there is a marketing myopia in the public sector due to the lack of a core business definition. Indeed, the Moroccan PA has undergone many reforms during the last decade. Innovative experiments have been conducted in many areas. Despite these many achievements, the action of the administration and its mode of operation are subject to criticism both from its users and on the part of civil society.

According to a satisfaction survey regarding the Moroccan PA that we have conducted to obtain citizens' opinions (El Yachioui and Aomari, 2015), it was clear that the perception of public services by users remains generally negative. The citizen as a balance of power, which is weighted against the individual citizen, experienced the relationship with the administration. Service was perceived as a favor rather than a right. The Moroccan PA is thus endangering its growth due to its lack of marketing orientation. So the aim of the present article is to show the characteristics of the public administrations and the marketing myopia in the operational component, which will allow us to propose an applicable marketing mix within the Moroccan PA to optimize their relations with citizens and to see how eadministration responds to a marketing approach.

\section{Characteristics of Public Administration}

\subsection{Private sector model vs. Public sector model}

Before highlighting the characteristics of Public Administration, the table below gives an overview of the important differences between the private sector and the public sector. Table 1 clearly shows that the public sector is governed by values that are totally different from those that lead the private sector. Thus, where the private sector depends on individual consumer choices, the public sector, on the other hand, depends on collective decisions. When price and demand drive the private sector, the public sector focuses on resource needs independently to some extent from price and demand.

Other characteristics of the public sector model are equity of needs, the search for justice, citizenship and collective action as a political instrument. In the end, while in the private sector a 
consumer can simply stop his relationship with the company, in the public sector he cannot get out of this relationship but only complain about it.

Table 1: Private Sector and Public Sector Model (Stewart and Ranson 1988)

\begin{tabular}{|l|l|}
\hline \multicolumn{1}{|c|}{ Private Sector Model } & \multicolumn{1}{c|}{ Public Sector Model } \\
\hline $\begin{array}{l}\text { Individual choice on the } \\
\text { market }\end{array}$ & Collective policy choice \\
\hline Request and price & Resource Requirement \\
\hline Private action & Public action open to all \\
\hline Market equity & Equity of Needs \\
\hline Search for market satisfaction & Search for justice \\
\hline Customer Reign & Citizenship \\
\hline $\begin{array}{l}\text { Competition as a market } \\
\text { instrument }\end{array}$ & $\begin{array}{l}\text { Collective action as an } \\
\text { instrument of policy }\end{array}$ \\
\hline $\begin{array}{l}\text { Stopping the relationship as a } \\
\text { stimulus }\end{array}$ & Claim as condition \\
\hline
\end{tabular}

\subsection{Characteristics: actors and processes}

We will see which actors and processes of the Public Administration to better understand this market.

\section{- Actors:}

In this section, we will present the Public Administration as an organization, as well as the main actors with whom it must interact, namely political authorities, citizens and private sector competitors. For the Public Administration as an organization, we must consider two main characteristics: first, its mission is often non-profit, and second, public administration organizations are politically responsible. A Public Administration organization is non-profit making. Its activities can generate profit, usually called "surplus", but it will serve to produce the services of the following period. In no case shall surplus or profit be used for private purposes. "However, most public sector organizations are expected to provide equitable, effective and efficient services that meet the desires and preferences of multiple" clienteles ", including users, players, donors, politicians, Spokespersons, the media and the general public "(Lamb,1987). Regarding being politically responsible, all actions and activities of a public sector organization are and must be transparent to be considered by the Society or political representatives potentially. There is nothing asked of the private sector. Even if the supply or delivery of Public Administration products can be provided by the private sector as well as by the public sector, the ultimate responsibility rests with those who are politically responsible (Dunleavy and O'Leary 1987).

Regarding political powers, they are very important for the Public Administration since they define the rules and give the direction to be taken. Politicians are responsible for the development of new products and are ultimately responsible for the activities and actions of the Public Administration. Concerning the citizens, their main characteristic is to form a group more heterogeneous than that of the customers. Most private companies are targeting their clients, hence the relative homogeneity of this group. The products of the Public Administration are consumed by a wide range of people, ranging from the worker to the doctoral student. Despite this great heterogeneity, citizenship refers to a notion of equality, that is to say, that all citizens are supposed to be treated equally regardless of the level of their income or any other criterion. "This idea is reinforced by the fact that many public services are free at the place of issue and the link between use and payment is long and tenuous.

Moreover, it is not clear which citizen is the consumer: is it the taxpayer, the patient, the pupil, the parent or society in general? (Collins and Butler, 1995). It may be added that citizens are obliged to be loyal to their nation, that is, they can not leave the relationship but must make their voices heard when they complain (Hirschman 1970). Compared to competitors in the private sector, public sector products are offered in a wide range of competitive environments, ranging from legal monopolies to almost perfect competition without any protective measures (Common and al., 1993). For example, Collins and Butler (1995) tell us that in England, Her Majesty's stationery department has a monopoly for the Parliament's press, but it is competing with private publishers for the other products in its range. Public service providers are increasingly exposed to the privatization threat they face.

\section{- Process :}

We can identify five major processes in the public sector: new product development, payment-billing cycles, delivery systems, internal market operations and evaluation of results. Product development is a fairly formal process. The ideas of new products are often issued by politicians or from an urgent request of the Society (which then pushes the politicians to submit the corresponding ideas). Before being applied to Public Administration, these ideas are somehow tested through the legislative and executive system. They are then adapted according to what is expressed by the political parties, the lobbies and more generally the interested public. The Public Administration, therefore, does not create its new products alone, even though it is the most qualified to do so. On the other hand, it advises politicians on new products, without taking responsibility for them.

We can identify two types of processes in the payment billing cycle. The first, the simplest, corresponds to the payment proportional to the use (for the realization of a new identity card for example). The second process is much more complicated. Costs are allocated and paid by taxes and other charges. Let us take the example of the social security system or the educational system of many countries. Many pay without ever having the opportunity to use these services. In Germany, studying at university is free. Everyone contributes to the functioning of the university system by paying taxes, but only a small portion of these people go to university and can benefit from it. 
These issues are difficult because the situation is often felt unfair by taxpayers who do not benefit from these services.

The delivery process is becoming increasingly complex. A few years ago, most of the products of the Public Administration were issued through this institution. Today, there is a multitude of ways to deliver products, using the private sector for example, or through private-public partnerships. Since 1998, for example, Central Park in New York is managed by Central Park Conservancy, a private, not-for-profit organization that has signed a contract with the Parks and Recreation Department of New York City.

The creation of internal markets is fairly recent. A few years ago, when a public organization worked for/helped another organization of the same type, there was no payment in return. On the other hand, it is increasingly the case now, following the mimicry on the private sector and its use of internal transfer costs. Even when there is no real competition, organizations evolve to resemble quasi-markets. Large organizations in particular play a "commercial role" (Common et al., 1993) by dividing themselves internally into suppliers and service buyers (creation of internal markets).

On the evaluation of results, it is particularly complicated in public administration according to Peter Smith (1993), because of the absence of performance indicators. That said, financial and quantitative indicators do not necessarily measure success in the public sector. Van der Valle and Bouckaert (2003) find that more and more information is needed on the effectiveness of "governance" as a whole, such as "quality of life" indicators. However, often these qualitative indicators are not understood by the Company, which is then problematic.

\subsection{The concept of the target market for a public administration}

A target market is "a set of buyers who share the same needs or characteristics that the company will have decided to satisfy" and a buyer is "the person who does a real act of purchase". According to De Quatrebarbes (1996) public marketing, and therefore marketing in public administration, "is addressed either to very broad targets, sometimes to restricted targets, individuals or companies".

In the Administration literature, there are many terms referring to purchasers of public administration services such as "customer", "consumer", "user", "stakeholder", "citizen", "taxpayer" or simply the "public" (Alford 2002). However, the Public Administration has four specificities that do not make it apprehend the client in the same way as most private companies:

\section{- Public administration does not need the customer as much as a private company:}

According to Lamb (1987), PA is less exposed to the market since she receives part of her income from the State and not only directly from the client who buys her services. For example, German universities are almost entirely financed by taxes and not by student contributions. This is why it is difficult to introduce the notion of the client in relation to students.

\section{- Clients are captive}

For most Public Administration services, clients are captive, either because there is no competing offer (the passport is issued only by the State), or because the (Children and adolescents are obliged to attend school until a certain age). Bon and al. (1977) find that "most administrations have rendered mandatory or indispensable the use of their services. The user is therefore forced to submit to the conditions that are made to him. This characteristic of the public sector is in complete contradiction with the principle of consumer sovereignty in the private sector, which stipulates that the customer can decide whether or not to buy, for example, bread.

\section{- Public administration must focus on groups with little interest}

While the private sector concentrates on market segments potentially interested in its offer, the Public Administration must concentrate on groups that are not interested or even opposed. A good example could be the large population of smokers directly targeted by anti-tobacco campaigns.

- Public administration often has a complementary role to private companies rather than a competitor role

The Public Administration must identify the citizens who are not or badly served and develop a marketing mix that is favorable to them rather than targeting the most profitable segments of consumers. Several authors even doubt the possibility of applying the concept of a customer to the public sector (Stewart and Ranson 1988, Swiss 1992, Frederickson 1992, Moe 1994, Pegnato 1997, Patterson 1998), explaining that this would reduce citizens to passive consumers That they must be active agents (Patterson 1998). Similarly, Alford (2002) states that "most public-client organization interactions differ from private consumer transactions", but also that "the notion of exchange [...] can be broadened in a stronger sense The importance of the responsiveness of directors to their public ". By making a distinction between citizen and client, Alford (2002) argues that the value delivered by the Public Administration is perceived as a public value by citizens and as a private value by clients.

However, the expression of wishes and preferences regarding the values to be offered and the price they must cost is only possible for the citizen during an election. Thus the citizen not only pronounces on the public value but also on the private value (the customers are supposed to consume). It is quite different for the private sector, where "the exchange is direct, in the sense that the consumer's money is directly related to the private value they receive" (Alford 2002). The solution proposed by Alford (2002) is to broaden the concept of exchange that dominates the private sector: first, things other than tangible items can be exchanged, such as friendship, respect, and honesty; second, there may be more than two parties involved in the exchange. Nevertheless, with regard to the target market, marketing has at least two important potential roles: 


\section{- Marketing can help the Public Administration to identify the target market and better reach its consumers.}

"Marketing in public services allows for a bottom-up relationship between the public and the organizations, which leads to more adapted services and therefore an increased resistance to direct or indirect competition" (Lamarche 1998). Analyzing consumer behavior can provide a better understanding of the utility customer. The analysis of the market and consumer behavior of the Public Administration is often non-existent.

Traditionally, the needs and expectations of citizens are conveyed to the Public Administration only through the results of the political elections. Of course, political parties are testing to some extent their action plan to determine the potential reactions of citizens. However, they test rather general ideas about an action (often perceived negatively, like introducing a new tax), but they do not determine the detailed characteristics of a response to a neutral action (what are the characteristics of a citizen who has just passed his driving license). In addition to analyzing consumer behavior, continuous marketing feedback can help keep consumer data up-to-date: private organizations are gathering continuous information about the changing environment and $\mathrm{On}$ its performance. Non-profit organizations are less focused on collecting vital information about the results of their actions and the events that are happening on the market.

- Marketing can help to apprehend the consumer more individually, without losing the efficiency of mass production. A good segmentation allows knowing first of all which different types of consumers exist. If one takes the example of the education sector, two segments of consumers must be treated differently: on the one hand the students themselves and on the other the taxpayers who do not benefit from university education. However, marketing has its limitations. Taking into account the heterogeneity of the population through segmentation is limited in the Public Administration by the fact that all citizens must be treated equally by the public services.

The private sector postulates that one can not serve everyone in the same way, which is not applicable in the Public Administration because "it is statutorily mandatory to deliver a public service on a universal basis" (Walsh 1991). There are, however, exceptions to this rule if we consider foreigners who do not speak the language of the country in which they reside: they can benefit from a public translator and a certain number of aids that are not accessible to other persons. Marketing can in any case help to understand the citizen, whatever role he plays at any time, whether he is a client, a taxpayer, a user, etc.

\section{A marketing-mix poorly defined in the Moroccan PA}

Moroccan PA put their growth in danger due to their lack of marketing orientation, especially their operational marketing. To do this, we will demonstrate the marketing myopia in each element of the marketing mix in Moroccan PA.

\subsection{Product}

The PA's products have the characteristics of so-called "public goods". Those goods are consumed jointly, that is to say, that consumers are not rivals (Samuelson 1954). Moreover, it is impossible to stop people who do not pay for these public goods from consuming them (Varian 1992). For example, streetlights illuminate the streets for everyone, whether they contribute or not, through the raising of taxes. There is rarely the issue of nonrivalry in the PA, when you take for example the seating system in Moroccan universities. Seats are allocated according to the results of the baccalaureate. Thus, although seating at Moroccan universities is a product of the PA, it cannot be considered as a public good since there is not a spot for everyone; students are rivals because they can be excluded from selection. The PA provides services rather than goods. Services have the following characteristics: intangibility, inseparability, heterogeneity and perishability (Parasuraman et al. 1988; Zeithaml et al. 1985). In addition, the typical problems encountered in services are the same in the PA. The inviolability implies problems of sampling and evaluation. The inseparability limits the number of possible operations. The heterogeneity makes quality control more difficult, and the perishability involves storage issues as soon as demand fluctuates (Parasuraman et al. 1988; Zeithaml et al. 1985).

The equipment, constraints, and duties are the main products of the PA (Butler and Collins 1995). Equipment corresponds to assets such as bridges and museums, or they correspond to services, such as health, education, the police, so citizens view them positively. Regarding constraints, they prohibit certain behavior (such as banning smoking in public places) and act as laws and regulations. Such laws and regulations are beneficial to the public interest but hinder interest. The individual constraint is seen as the price to pay for the public benefit. As for duties, they ensure that certain behavior is required and are usually accompanied by sanctions.

Again, in view of the general interest, citizens are asked to make efforts, such as paying taxes. Product development is rarely done in the Moroccan PA. Indeed, it is rather the politicians or strong demand from companies that create new products. Politicians often have to find the right balance between losing popularity points and acting for the good of the nation. For example, the introduction of a new tax is not highly appreciated by the public; however, it may be the solution for a heavily indebted country. These new product developments often take place just after the elections and not just before. Consumers prefer products that offer the best quality, highest performance, and best attributes.

Thus product improvement is needed. But the Moroccan PA does not much improve their products; in particular, they do not recognize themselves to be in competition. But even when there is no competition, we see the importance of the increase of improved products, as is the case for the administration's' monopoly (the issuing of identity cards). The dissatisfied customer cannot turn to a competitor. Instead, he can express his dissatisfaction through demonstrations, which generates 
additional costs. These include the violent demonstrations in front of the Moroccan Parliament, as a sign of discontent, or the 20th February movement (M20) which emerged from young Moroccans' dissatisfaction. These events generate huge costs. Besides the difficulties in developing and improving products, an essential step for the Moroccan PA is what it sells. Therefore, we will explain the concept of "generic". According to Kotler and Levy (1969), a modern company that sells soap defines its core product as "cleaning" and not as soap.

The Moroccan PAs often complain about the lack of citizens' interest in their services and products. We can, therefore, speak about marketing myopia in the public sector due to the lack of definition of its core business. Levitt (1960) gave the example of the railway system. The reason they defined their industry incorrectly was that they were railroad oriented instead of transportation oriented; they were product oriented instead of customer oriented. Similarly, we can say that there is certainly a public service demand, but it is not satisfied properly. In this case, citizens are looking to meet their demand outside the public sector (e.g. using a private clinic or private university) or they resort to public systems in other countries.

\subsection{Price}

Moreover, according to Christian Dussart (1994), "the price plays a crucial role in the strategy of organizations, it has become the nerve center." However, the PA is non-profit, meaning that private persons do not receive the profit. The PA's activities may generate profits, called "surplus" but will be assigned later to the provision of future services. Unlike the private sector, in which the adaptation to market realities is indicated by the fact that the customer is ready to buy at that price, this is more difficult for the public sector because the Moroccan citizen is forced to buy there (through the taxes they pay), or it has no alternative, as the PA is a monopoly (we can only get our birth certificate or driving license through the PA). A fixed price must be precisely aligned with the positioning of the product. The Moroccan PA is a monopoly, and therefore there is no competition against which to position its products and services. There is, however, a positioning through the price within the Administration: imagine driving licenses cost nothing. Citizens would be inclined not to care, to lose them and therefore generate more renewal work for administrative officers.

\subsection{Place}

Distribution is defined as "all activities of a company to make the product or service available for targeted consumers" (Kotler et al. 2005). For many services, such as the delivering of national identity cards (NIC), additional distribution points do not increase the demand for the service; we repeat that the Administration has the monopoly for issuing NIC. But the opening of these additional facilities reduces public transaction costs and can lead to greater satisfaction. Here one can speak of a balance between cost and increased customer satisfaction which the Moroccan public administration does not take into consideration.

\subsection{Promotion}

Current marketing requires more than just creating a quality product, setting the price and making it available. Companies must also communicate with existing and potential customers. It is also the critical point on which the efforts of a company must bear in building good relations with its customers. Various traditional means of communication can be used, both by the central administrations and local authorities such as advertising (information campaigns on road safety, for example), the "sales force" (open house), the "promotion of sales" (tax reduction for online tax declarations), and public relations. Now it has long sought to animate the Administration through promotional activities. In New York, for example, the Economic Development Department has appealed to the advertising agency, Well, Rich and Green to develop a marketing campaign for the city of New York. The result was the famous slogan "I $\bullet$ NY" that we can often see on T-shirts sold in the city and even circulating around the world. Morocco is still not aware of the importance of its cities.

There are private or international organizations that promote the most beautiful cities in Morocco, such as the city of Chefchaouen which was ranked the sixth most beautiful city in the world by the prestigious Condé Nast Traveller magazine or the website TripAdvisor which ranked the city of Marrakech as one of the most beautiful destinations in the world. Butler and Collins (1995) show that "communication campaigns informing the public of the benefits and value of public services are becoming increasingly important." Marketing can help improve the negative image by, for instance, explaining what the reasoning behind a certain requirement is. For example, it can adequately explain why it is necessary to wear a seat belt when driving. This reduces the negative feelings experienced in respect of this rule to follow. An anti-smoking campaign is certainly badly perceived by smokers, but the Administration has to lead it anyway. But promotion remains the last concern of the Moroccan public administrations.

\section{A marketing-mix proposal for the Moroccan PA}

We present in this part the implementation of the "4P" in the public sector. To do this, we will briefly present each element of the mix while illustrating these with Moroccan examples, but also other countries that the Moroccan PA can take as a model to understand the differences and similarities between the private and public sector. We then demonstrate how the e-administration answers to a marketing approach. In fact, aware of the ICT's importance, Morocco has launched e-administration programs to develop a digital technology. Finally, we discuss the limits of the implementation of each element of the mix in the PA.

\subsection{Product}

According to Kotler et al. (2005), the product dimension has eight tools: variety, quality, design, attributes, branding, packaging, services, and warranties. 
Table 1: Product dimension in the public sector

\begin{tabular}{|c|c|}
\hline Marketing Tools & Examples in public administration \\
\hline $\begin{array}{l}\text { Variety: the number of } \\
\text { different products } \\
\text { contained in a product } \\
\text { class }\end{array}$ & $\begin{array}{l}\text { Different types of driving license are } \\
\text { available in Morocco: category A for } \\
\text { motorcycles, Class B for cars, trucks, } \\
\text { category C and category D for bus }\end{array}$ \\
\hline $\begin{array}{l}\text { Quality: all the } \\
\text { attributes and } \\
\text { characteristics of a } \\
\text { product or service that } \\
\text { have the ability to } \\
\text { satisfy expressed or } \\
\text { implied needs }\end{array}$ & $\begin{array}{l}\text { The new biometric passports are } \\
\text { considered higher quality than } \\
\text { traditional passports because they } \\
\text { offer a higher level of security and } \\
\text { protection against counterfeiting and } \\
\text { false papers. }\end{array}$ \\
\hline $\begin{array}{l}\text { Design: attributes and } \\
\text { packaging have much } \\
\text { to do with aesthetics, } \\
\text { but also the } \\
\text { composition of the } \\
\text { product or service. }\end{array}$ & $\begin{array}{l}\text { The European version of the } \\
\text { biometric passport contains a digital } \\
\text { image and a biometric fingerprint on } \\
\text { a RFID chip while in the Moroccan } \\
\text { version, there is a digital image on } \\
\text { the chip. }\end{array}$ \\
\hline $\begin{array}{l}\text { Brand: a name, term, } \\
\text { design, symbol, } \\
\text { design, or a } \\
\text { combination of these, } \\
\text { to identify the goods } \\
\text { or services of one } \\
\text { seller or group of } \\
\text { sellers and to } \\
\text { differentiate them } \\
\text { from their } \\
\text { competitors. }\end{array}$ & $\begin{array}{l}\text { Public universities can have a brand. } \\
\text { In Germany, the brands "University } \\
\text { of Cologne" and "Munich University" } \\
\text { have the image of a more selective } \\
\text { recruitment than the "University of } \\
\text { Hamburg." In Morocco, we can give } \\
\text { the example of the Higher Institute of } \\
\text { Commerce and Business } \\
\text { Administration (ISCAE). }\end{array}$ \\
\hline $\begin{array}{lr}\text { Services: } & \text { activities, } \\
\text { benefits } & \text { or } \\
\text { satisfactions } & \text { available } \\
\text { for sale. } & \end{array}$ & $\begin{array}{l}\text { When you buy a passport in Belgium, } \\
\text { one is expected to get it in a shorter } \\
\text { amount of time. You can access this } \\
\text { service by paying three to five times } \\
\text { the usual price. }\end{array}$ \\
\hline $\begin{array}{l}\text { Warranties: } \\
\text { agreements between a } \\
\text { buyer and a seller of } \\
\text { goods or services, } \\
\text { giving details of the } \\
\text { conditions for which } \\
\text { the seller will cover } \\
\text { the repairs without the } \\
\text { buyer having to pay } \\
\text { extra. }\end{array}$ & $\begin{array}{l}\text { Any social security system can be } \\
\text { considered in a sense as a guarantee: } \\
\text { the conditions are set according to the } \\
\text { type of disease. The country finances } \\
\text { treatments. }\end{array}$ \\
\hline
\end{tabular}

Source: Author: The remaining definitions, as well as the list of marketing tools included, are adapted from Kotler et al. (2008)

\subsection{Price}

According to Kotler et al. (2005), the function of prices has five tools: pricing, rebates, discounts, payment terms and credit terms.

Table 2: Price dimension in the public sector

\begin{tabular}{|c|c|}
\hline Marketing Tools & $\begin{array}{lll}\text { Examples in } & \text { public } \\
\text { administration } & & \\
\end{array}$ \\
\hline $\begin{array}{l}\text { Pricing: contains the sales price } \\
\text { of all the products available, } \\
\text { presented in a catalogue or list. }\end{array}$ & $\begin{array}{l}\text { The rates for a license, for an } \\
\text { ID card or passport }\end{array}$ \\
\hline $\begin{array}{l}\text { Discounts and rebates: price } \\
\text { reductions over time. The } \\
\text { discounts are } \\
\text { specifically for } \text { granted } \\
\text { damaged goods. }\end{array}$ & $\begin{array}{l}\text { An example would be that of } \\
\text { delivery of the French } \\
\text { government, which granted } \\
\text { 20-euro reduction in } 2006 \text { to } \\
\text { taxpayers who filed their tax } \\
\text { returns on the Internet (Sanz } \\
\text { 2006). }\end{array}$ \\
\hline $\begin{array}{l}\text { Payment Time: is the period in } \\
\text { which the payment is due. }\end{array}$ & $\begin{array}{l}\text { In Germany, companies have } \\
\text { to pay VAT at the time of } \\
\text { billing. But companies with } \\
\text { annual sales of less than } \\
250,000 \text { Euro can only pay } \\
\text { their VAT when the bills of } \\
\text { their customers are met. }\end{array}$ \\
\hline $\begin{array}{l}\text { Credit terms are the terms on } \\
\text { which the parties agreed. Most } \\
\text { of the times it is the number of } \\
\text { days between delivery and } \\
\text { payment, but also discounts for } \\
\text { advance payment or penalties in } \\
\text { case of late payment. }\end{array}$ & $\begin{array}{l}\text { Example penalty: you pay } \\
\text { extra when you do not pay } \\
\text { taxes on time. }\end{array}$ \\
\hline
\end{tabular}

\subsection{Place}

Four tools are related to the distribution: the channels, coverage, range and places. We must ask two questions to select the appropriate channel: first, who should manage the channel, the Administration itself or a private company? Second, what is the most appropriate channel for delivering a specific service? The Administration may provide service to a physical building or the Internet. In October 2005, Estonia was the first country to allow elections online. The coverage was required to meet customer needs. France chose to keep intense coverage of Commons, the lowest level of the administrative division composed of large cities as well as villages. We mean by "assortment" the choice of products and services to be offered by the same distribution channel. The agency for German Federal Employment was decentralized and offered only jobs in the respective regions; now it has been centralized and offers jobs in all of Germany. Places are locations where one can find the physical buildings. 
France has decided to sell some administrative buildings in town centers and moved administrations to the periphery so as to collect more money.

\subsection{Promotion}

According to Kotler et al. (2005), there are four tools related to communication: advertising, sales force, sales promotion and public relations.

Table 3: Dimension communication in the public sector

\begin{tabular}{|c|c|}
\hline Tools & $\begin{array}{l}\text { Examples in public } \\
\text { administration }\end{array}$ \\
\hline $\begin{array}{l}\text { Advertisement "any form of } \\
\text { remote presentation and } \\
\text { promotion of ideas, goods, or } \\
\text { services by an identified } \\
\text { sponsor" (Kotler et al. 2005, p. } \\
905 \text { ). }\end{array}$ & $\begin{array}{l}\text { Awareness campaign by the } \\
\text { Moroccan government: } \\
\text { diabetes road safety }\end{array}$ \\
\hline $\begin{array}{l}\text { Salesforce is an "a personal } \\
\text { demonstration by business to } \\
\text { generate sales and build } \\
\text { customer relationships" (Kotler } \\
\text { et al. 2005, p. 917). }\end{array}$ & $\begin{array}{l}\text { Open days held in police } \\
\text { stations in several countries } \\
\text { to inform citizens about } \\
\text { police work and to build } \\
\text { relationships. }\end{array}$ \\
\hline $\begin{array}{l}\text { Sales Promotions: "Short-term } \\
\text { incentives for the purchase or } \\
\text { sale of a product or service" } \\
\text { (Kotler et al. 2005, p. 920). }\end{array}$ & $\begin{array}{l}\text { In 2006, the French } \\
\text { government offered a 20- } \\
\text { euro reduction to taxpayers } \\
\text { who filed their tax } \\
\text { declaration online (Sanz } \\
\text { 2006). }\end{array}$ \\
\hline $\begin{array}{l}\text { Public } \text { Relations include } \\
\text { "creating good relations with } \\
\text { different audiences for a } \\
\text { company to get positive } \\
\text { publicity, to build a good image } \\
\text { and to wash away negative } \\
\text { rumors, stories or events that } \\
\text { can harm the company's image. } \\
\text { The main PR tools include press } \\
\text { relations, product promotion, } \\
\text { corporate communications, } \\
\text { lobbying, and the board } \\
\text { "(Kotler et al. 2005, p. 919) }\end{array}$ & $\begin{array}{l}\text { Numerous Internet sites } \\
\text { where the Administration } \\
\text { gives information about its } \\
\text { organization, such as the } \\
\text { Moroccan Ministry of } \\
\text { Finance website. }\end{array}$ \\
\hline
\end{tabular}

Source: Author: The remaining definitions, as well as the list of marketing tools included, are adapted from Kotler et al. (2008)

\section{E-administration: a marketing approach}

\subsection{E-administration: a very ample offer of product and/or services}

Digital products are either scanned information products, as offered by open data, or scanned related services as proposed by the digital administration. Digital products are not produced in their consumption but are duplicated to infinity, and they have negligible physical costs of production and distribution. Web 2.0 allows for the sharing of services and expertise because of its community focus and its ability to build a digital identity, such as finding one's way or the organization of events. The individual expresses himself, he participates in the debate, and he becomes critical, emerging as an active player.

\subsection{E-administration: a pricing policy to build}

The specificity of non-market services is that the price is set below their cost price or even that they are free. The public sector must often demonstrate the value of their products according to the general interest. There are two aspects: the dematerialization of procedures and the availability of public data. Dematerialization is an opportunity to generate economies of scale in both study phases of realization and use of resources. The cost of treatment is a hundred times lower than a paper process and ten times less than a magnetic treatment. The release of public data, commonly known as open data for the benefit of citizens is an unprecedented opportunity for social and economic innovations. It is an innovation that facilitates information for citizens and a better understanding of public policies, contributing to greater involvement of everyone. In Morocco, the Ministry of Industry, Trade, and New Technologies has introduced a first version of the website data.gov.ma in March 2011, making Morocco a pioneer in the field of Open Data platform. But, despite its innovative character, the Moroccan initiative for Open Data has not experienced the interest it deserved, and the published datasets were limited.

\subsection{E-administration: a local distribution}

The Internet provides a distribution channel that makes saving money possible at the same time as increasing customer satisfaction. Filling in online tax declarations is regarded by many citizens as a benefit to them, as well as being cheaper for the Administration. The presence of many regional and local institutions can improve the satisfaction of collective welfare. The electronic administration appears as a way to rethink the distribution of existing services (portals, mobility), rearrange (combine on the same support functions of information, communication and transaction terms) and also, increasingly, to invent new services (collaborative encyclopedias associating users and administrations). But the provision of online services (informational, interactive, transactional) via a window or front office represents the tip of a processing and distribution management (back office), which is also modified extensively.

\subsection{E-administration: a more interactive communication}

One of the advantages of e-administration, regarding communication, is to facilitate and speed up communication between the administration and users and with partners, including the use of Web 2.0. The latter, commonly called "social Internet" allows you to create new modes of exchange and communication within the administration and with citizens. It meets the needs to express, share and react in real time.

\section{Application limits of the marketing-mix in the Moroccan PA}

The first difficulty is the evaluation of performance. To improve a product or service, we must know the consumer, but we must also assess performance. Nevertheless, we must not forget that the performance indicators for services are harder to implement than 
goods, even in the private sector. Indeed, the level of satisfaction of a service depends on the interaction with the customer or consumer, and that helps determine the quality of service. The second limit is that the PA does not often decide about its product; it is rather political.

Although the Administration often has a monopoly and has no competitors, it cannot act as it wishes. It must take into account four constraints. First, the Administration cannot fix excessive prices: citizens decide to stop buying services or products. If the license were too expensive, many people would rather not drive or travel by bicycle. Even when there is a legal limit to the fixed price, as is the case for taxes, the Administration cannot indefinitely require very high taxes. Citizens cannot get out of the contract, but they can make claims and protests against high taxes, which is very costly for the Administration. They can exit the contract by leaving the country. The second constraint is that the pricing policy, in this case, is difficult to implement. Third, it is not only the financial aspects that have to be taken into account in pricing decisions. It must also rely on the well-being of the Administration and the non-financial benefits; the prices seem impossible to estimate. The best examples seem to be natural disasters or defensive wars, where prices are just impossible to determine, The fourth constraint is that most often the Administration is funded by state and local taxes, while the services are provided for free, which can influence the consumer in many ways.

There are at least three specific constraints that are not found in the private sector. First, we must take into account the aspects of security and control, which do not facilitate the outsourcing of services and limit Internet distribution. On the issue of outsourcing, one can think of issuing passports and the danger associated with the delegation of control over the service. We could still appeal to the onerous outsourcing rules and strict conditions on the private partner, but the population would never accept it and maybe after a few years, the private company might decide not to follow the rules and issue passports to anyone. The Internet is not suitable for all types of services.

Nevertheless, more and more services are available, and egovernment is a very interesting area of research. As we have already said, it is possible to fulfill one's tax return in Morocco, and Estonia was able to vote for a city council online in 2005 . The second limit is that the increase in distribution points and channels does not necessarily increase customer satisfaction. If the PA decides to build a new building, it is the taxpayer who finances it, and he or she may not appreciate this expense. A final limit concerns the place of distribution, which is often contingent on administrative areas, that is to say, a set of administrative sector basis (and not on population density considerations) or contingent on existing buildings. Changing the physical location of buildings or administrative boundaries is a more complicated task to achieve in the public sector than in the private sector.
There are also limits related to promotional activities. The communication must remain neutral. It does not create an image but only seeks to inform. In the case of the referendum on the Moroccan Constitution in 2011, for example, it was supposed to inform only on the content of the Constitution. Only political parties could produce the actual advertising about the Constitution. But during the campaign, we saw that the separation between politics and administration was blurred. There is also an ethical limit: it is not recommended to share only the benefits of a product of the Administration; one should also communicate the costs. This is part of marketing since it is to build an image of honesty for the Administration. Finally, marketing can provide information on the benefits of a service. In this case, it can limit the negative impact on the satisfaction of a consumer, but it cannot make the consumer fully happy with the service. According to Levitt (1960), citizens hate paying taxes no matter what and do not like to cooperate with the state to complete forms. It is more useful to minimize the effort required by citizens.

\section{Conclusion and Discussion}

In this conclusion, we will lead a general discussion of our article before looking at the limits that we have identified and future research ideas that could be pursued. Having highlighted the marketing myopia, which lies within the Moroccan PA, we have shown the applicability and limitations of the marketing mix in it. We also demonstrated that e-administration responds to a marketing approach that we can incorporate into the 4P in any PA in Morocco., something that will allow the public to know the heart of the business and improve the PA's relationship with its users. The primary purpose of this article is to show that the marketing and the public sector are similar, although there are still differences. However, it is not necessary to set up new marketing specific to the public sector, but rather to adopt a different angle within the marketing discipline. The Moroccan PA should listen more to marketers. However, it must remain vigilant and not think that marketing is capable of solving everything: marketing is not a panacea but only a process that helps one manage the public sector more effectively.

\section{Limits and future research paths}

The main limit of this article is that we have processed a very operational part of marketing, but marketing also deals with more strategic issues. Thus, the coordination of a comprehensive marketing plan is the key to maximum efficiency. Finally, as far as research opportunities in the field of marketing and public sector: it would be interesting to study the relationship between the PA and citizens. And, based on the CRM principles, transpose these into the public domain, which could lead us to speak of a new concept, namely the Citizen Relationship Management. However, this relationship is strongly influenced by political activities. It would be wise to analyze the relationship between these three actors. 


\section{References}

- Alford John (2002) Defining the client in the public sector: a social-exchange perspective, Public administration review, 62(3), 337-346, CrossRef

- Butler Patrick, Collins Neil (1994) Political marketing: structure and process, European journal of marketing, 28(1), 19-34, CrossRef

- Butler Patrick, Collins Neil (1995) Marketing public sector services: concepts and characteristics, Journal of marketing management, 11(1-3), 83-96, $\underline{\text { CrossRef }}$

- Butler Patrick, Collins Neil (1996) Strategic analysis in political markets, European journal of marketing, 30(10/11), 32-44.

- Bon Jérôme, Delabre Alexis, Nioche Jean-Pierre (1977) Les abus du marketing, Revue française de gestion, 8(1), 21-31.

- Common Richard, Flynn Norman, Mellon Elizabeth (1993) Managing public services: competition \& decentralisation, Butterworth-Heinemann, Oxford.

- Collins, Neil and Butler, Patrick (2003) When marketing models clash with democracy. Journal of Public Affairs 3(1), 52-62, CrossRef

- Dussart, Christian (1994) Capitalism versus capitalism, in Michael J Baker (ed.) Perspectives on Marketing Management, Vol. 4, Chichester : John Wiley \& Sons.

- Dunleavy Patrick, Hood Christopher (1994) From old public administration to new public management, Public money \& management, 14(3), 9-16, CrossRef

- El Yachioui.M and Aomari.A, (2015), Dematerialization and Use of Social Networks in Public Administrations: Emergence of Citizen Relationship Management (CiRM) in Morocco, Journal of Global Academic Institute Business \& Economics, Vol. 1, No. 2, 134-149.

- Eric Billiaert et Etienne Veyret (2009) e-Gov 2.0 : les clès du succès, choisir et construire son chemin vers le succès, les meilleurs pratiques, les modes opératoires, Livre Blanc.

- Frederickson George H. (1992) Painting bull's eyes around bullet holes, Governing, 6(1), 13.

- Hirschman Albert O. (1970) Exit, voice and loyalty: esponses to decline in firms, organisations and states, Harvard University press, Massachussetts.

- Hood, Christopher (1991) A public management for all seasons? Public Administration 69(1), 3-19, CrossRef

- Kaplan, Andreas M. (2007) Apports et limites du marketing dans l'Administration Publique. Ecole Nationale d'Administration (ENA), Strasbourg.

- Kotler, Philip (1972) A generic concept of Marketing. Journal of Marketing 36(2), 46-54, CrossRef

- Kotler, Philip (1979) Strategies for introducing marketing into nonprofit organizations. Journal of Marketing 43(1), 37-44, CrossRef
- Kotler, Philip, Armstrong, Gary, Wong, Veronica and Saunders, John (2008) Principles of marketing: Fifth European edition. Prentice Hall Financial Times, Harlow, England.

- Kotler, Philip and Levy, Sidney J. (1969) Broadening the concept of marketing. Journal of Marketing 33(1), 10-15, CrossRef

- Kotler, Philip and Murray, Michael (1975) Third sector manage- ment - The role of Marketing. Public Administration Review 35(5), 467-472. Kotler, Philip and Zaltman, Gerald (1971) Social marketing: An approach to planned social change. Journal of Marketing 35(3), 3-12, CrossRef

- Lamarche Thomas (1998) Développement du marketing et recomposition du service public, Sciences de la société, 43, 49-66.

- Lamb, Charles W., Jr. (1987) Public sector marketing is different. Business Horizons 30(4), 56-60, CrossRef

- Levitt Theodore (1960) Marketing myopia, Harvard business review, 38 (4), 26-44, 173-81.

- Ministère des Finances(2013), Dossier : Les e-services du MEF, $n^{\circ} 53$

- Moe, Ronald (1994) The 'reinventing government' exercise: Misinterpreting the problem, misjuding the consequences, Public administration review, 54(2), 111112, CrossRef

- Mohammed Amine Benabellah (1994), Les rapports entre l'administration et les citoyens, Remald, $\mathrm{n}^{\circ} 5$, p. $9 \mathrm{ff}$.

- Patterson Patricia (1998) Market metaphors and political vocabularies, Public productivity and management review, 22(2), 220-231, CrossRef

- Parasuraman, A., Zeithaml, Valarie A. and Berry, Leonard L. (1985) A conceptual model of service quality and its implications for future research. Journal of Marketing 49(4), 41-50, CrossRef

- Parasuraman, A., Zeithaml, Valarie A. and Berry, Leonard L. (1988) SERVQUAL: A multi-item scale for measuring customer percep- tions of service quality. Journal of Retailing 64(1), 12-40.

- Pegnato Joseph A. (1997) Is a citizen a customer? Public productivity and management review, 20(4), 387-394, CrossRef

- Smith Peter (1993) Outcome related performance indicators and organizational control in the public sector, British journal of management, 4(3), 135-151, CrossRef

- Shaw, A. W. (1912) Some problems in market distribution. The Quarterly Journal of Economics 26(4), 703-765, CrossRef

- Stewart John, Ranson Stewart (1988) Management in the public domain, Public money and management, 8(1/2), 13-19.

- Swiss James (1992) Adapting total quality management (TQM) to government, Public administration review, 52(4), 356-362, CrossRef 
- Van de Walle Steven, Bouckaert Geert (2003) Comparer les niveaux de confiance des citoyens et de satisfaction des utilisateurs en tant qu'indicateurs de "bonne gouvernance":difficile d'établir un lien avec les indicateurs de confiance et de satisfaction, Revue internationale des sciences administratives, 69(3), 383-400.

- Varian Hal R. (1992) Microeconomic analysis, 3rd ed., W.W. Norton \& Company, New York.

- Walsh Kieron (1991) Citizens and consumers: marketing and public sector management, Public money and management, 11(2), 9-15, CrossRef 